\title{
Reproductive biology of Sodhiana iranica (Brachyura: Gecarcinucidae) from Southern Iran
}

\author{
Sana Sharifian ${ }^{1}$, Ehsan Kamrani ${ }^{2}$ \& Mohsen Dehghani ${ }^{1}$ \\ 1. Department of Marine Biology, University of Hormozgan, P.O. Box 3995, Bandar Abbas, Iran; \\ sharifian.phd@hormozgan.ac.ir, Mohsen.dehghani64@gmail.com \\ 2. Department of Fisheries, University of Hormozgan, P.O. Box 3995, Bandar Abbas, Iran; Ezas47@gmail.com
}

\author{
Received 15-II-2016. Corrected 25-VIII-2016. $\quad$ Accepted 26-IX-2016.
}

\begin{abstract}
Freshwater crab, Sodhiana iranica, is an endemic gecarcinucid crab that has been recently reported from Southern Iran. This research examined some reproductive aspects of $S$. iranica from Eelood freshwater spring, Southern Iran. Crabs were haphazardly sampled from April 2012 to April 2013, on a bimonthly basis. Measurements of Gonado-Somatic Index (GSI), Hepato-Somatic Index (HSI), oocyte diameter, and other aspects such as carapace width $(\mathrm{CW})$ and total body weight $(\mathrm{TW})$ were made in the captured specimens. Results showed a single seasonal reproductive cycle. Maturation and spawning occurred from December 2012 to April 2013 during the study period. The peaks of HSI were observed in April 2012 and February 2013. The oocyte diameter showed its most significant increase between August 2012 and February 2013. Considering the single seasonal breeding of $S$. iranica, a correct management, during the reproductive cycle, is necessary to support a healthy stock of this crab. Rev. Biol. Trop. 65 (1): 365-373. Epub 2017 March 01.
\end{abstract}

Key words: reproduction, gonado-somatic index (GSI), freshwater, crab, Decapoda.

There are more than 6800 species of brachyuran crabs distributed in all over the world. Of all species, over one-fifth are true freshwater crabs. Primary freshwater crabs have been introduced as land-locked organisms (Yeo et al., 2008; Cumberlidge, et al., 2009), as they are able to complete their life cycle independently of the marine environment. They are one of the most ecologically important macro-invertebrate groups (Yeo et al., 2008) which have the most number of species compared to the other decapod crustacean groups (Ng, Guinot, \& Davie, 2008) in inland waters worldwide.

In general, the freshwater crab fauna is poorly known in Iran. The gecarcinucid Sodhiana rokitanskyi (Pretzmann, 1971), and its taxonomy has been widely discussed by Kamrani, Ng, Mirzadeh, and Nakhodai (2009). The type locality of $S$. rokitanskyi occurs near a hot spring in Geno, Southern Iran (Kamrani, Ng,
Mirzadeh, \& Nakhodai, 2009); this area was located about $200 \mathrm{~km}$ to the East of Bastak, Iran. Recent studies introduced more species of freshwater crabs such as Potamon bilobatum (Brandis, Storch, \& Türkay, 2000) from Northern Iran (Potamidae, cf.; Nasrollahzadeh, Noveirian, \& Soutohian, 2011) and Potamon ilam (Keikhosravi \& Schubart, 2014) from Western Iran (Potamidae, cf; Keikhosravi, \& Schubart 2014). All rivers populated by $P$. ilam rise on the Western most slopes of the Zagros mountains in Western Iran; and this work increased to 22 the number of species in the genus Potamon.

The gecarcinucid fresh water crab Sodhiana iranica has been recently reported from Bastak (the same type of locality as $S$. rokitanskyi), Southern Iran for the first time as a new species. (Sharifian, Kamrani, \& Sharifian, 2014). The species inhabits a freshwater springs located in a semi-mountainous area in Iran 
(Eellod Area, 431 m.a.s.1.), covered by dense stands of common reeds and salt cedar trees in the periphery, with mats of green algae on the bottom (Sharifian, Kamrani, \& Sharifian, 2014). S. iranica represents the fourth species of Sodhiana, and is the second one known from Iran. Recently, some information about oogenesis and ovarian development of S. iranica has been discussed (Sharifian, Kamrani, Safaie, \& Sharifian, 2015). Histologically, the female germ cells were classified into seven different stages, and four ovarian developmental stages were found for females, based on the number and types of oocytes present in each stage. Besides, in a previous study, $S$. iranica morphometric variations have been reported and the authors determined that the growth of this crab is isometric (Sharifian, \& Kamrani, 2015).

Reproductive biology plays a critical role in population dynamics and life history strategies of crustaceans. Reproductive biology of brachyuran crabs is extremely variable for different species in terms of egg's production and offspring's survival (Lopez-Greco, Hernández, Bolaños, Rodríguez, \& Hernández, 2000). Reproductive biology studies provide basic information for stock management which is necessary to establish plans directed for sustainable management of living crab resources. The determination of breeding periods is controlled by a complex interaction of endogenous and exogenous factors, allowing both intra and interspecific variations, dealing with the duration of the reproductive season (Sastry, 1983).

Although numerous reports on reproductive biology of marine, intertidal and estuarine crabs are available (Kumar, Xiao, Venema, \& Hooper, 2003; Lestang, Hall, \& Potter, 2003; Sallam, 2005; Oh, Kim, Jeong, Suh, \& Cho, 2006; Henmi, \& Koga 2009; Omolara, 2010; Sahoo, Panda, \& Guru, 2011), limited works are available on the population and reproductive biology of freshwater, semiterrestrial or land crabs (Mansur, \& Hebling, 2002; Liu, \& Jeng, 2005; Hartnoll, Broderick, Godley, \& Saunders, 2009; Hartnoll et al., 2010; Pathre, \& Mina, 2010; Devi, \& Smija, 2013). In this study, we investigated the reproductive aspects in the recently described crab S. irani$c a$, to contribute with new information to assess the reproductive cycle of this species for optimum management.

\section{MATERIAL AND METHODS}

The sampling site was located in the freshwater springs of the Eelood area in Hormozgan province $\left(27^{\circ} 13^{\prime} \mathrm{N}-54^{\circ} 40^{\prime} \mathrm{E}\right)$, Southern Iran (Fig. 1). This region has a subtropical climate, with distinct spring and summer seasons. On an annual average, the study area has a $\mathrm{pH}$ of 8.09; salinity of $4 \%$, temperature ranging from 25 to $30{ }^{\circ} \mathrm{C}$, sediment Total Organic Matter (TOM) of $4.6 \%$ with a composition of $50 \%$ sand, 34 $\%$ silt, and $16 \%$ clay.

Few specimens of crabs were collected every two months from April (2012) to April (2013), to minimize the sampling pressure impact on the population. Specimens were collected by three people (by hand) during the daytime and over an approximate period of four hours from the freshwater springs of the Eelood area. Samples were placed inside iced plastic buckets and they were directly transported to the laboratory of Hormozgan University, at a distance of $235 \mathrm{~km}$ from the sampling site, Iran.

In the laboratory, crabs were identified and examined for sex identification, and female crabs were separated from the rest of the samples. The carapace width $(\mathrm{CW})$ was measured using vernier caliper $( \pm 0.05 \mathrm{~mm}$ accuracy) following $\mathrm{Ng}$ (1988). The total body weight (TW) was measured using a standard electronic balance (LA $310 \mathrm{~S}$ model, $0.0001 \mathrm{~g}$ accuracy). In order to measure the Gonado-somatic index (GSI) and Hepato-Somatic Index (HSI), we removed the carapace, and weighed the gonads and hepatopancreas.

The gonado-somatic index (GSI) was calculated according to the following equation (Giese, 1966):

$$
\mathrm{GSI}=\mathrm{GW}(\mathrm{g}) / \mathrm{TW}(\mathrm{g}) \times 100 ;
$$

where $\mathrm{g}=$ grams, GW is gonad weight and TW is total body weight. 


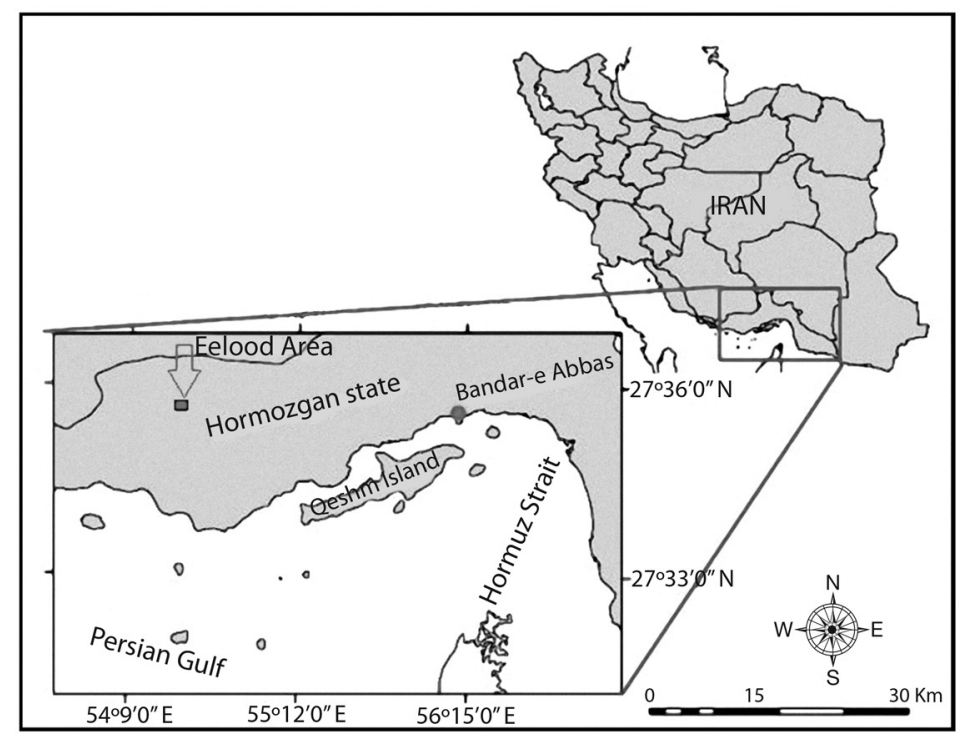

Fig. 1. Sampling locations in Eelood Area, Hormozgan Province, Southern Iran.

The hepato-somatic index (HIS) was calculated using the following equation (Clarke, 1977):

$$
\mathrm{HIS}=\mathrm{HW}(\mathrm{g}) / \mathrm{TW}-\mathrm{GW}(\mathrm{g}) \times 100 \text {; }
$$

where $\mathrm{g}=$ grams, HW is hepatopancreas weight, TW is total body weight, and GW is gonad weight.

The oocytes diameter was assessed by measuring the diameter of 40 oocytes found in each adult female ovary, and a mean was obtained per month. The information obtained from the ovaries of five adult females per month was pooled, for a total sample size of 200 oocytes diameter per month. The frequency of the ovarian maturation stages found was used as an index to determine the reproductive cycle in female crabs of $S$. iranica (Biswas, 1993). The maturation stages were divided into four stages (Sharifian, Kamrani, Safaie, \& Sharifian, 2015).

The mean carapace width $(\mathrm{CW})$ of males and females was compared using the Student t-test. A Chi-squared test $\left(\chi^{2}\right)$ was performed to detect significant deviations from a 1:1 sex ratio. Mann-Whitney $U$ tests were applied to test differences among the carapace width $(\mathrm{CW})$ of mature and immature females. Bimonthly mean oocyte diameters were compared using ANOVAs followed by post hoc Tukey's HSD. Kruskal-Wallis nonparametric test was used to determine the differences in GSI and HSI between different months. The relationship between GSI (\%) and HSI (\%) was studied using regression analysis and correlation coefficient (Zar, 1996).

\section{RESULTS}

A total of 158 crabs were collected during the study period: 89 males $(56.3 \%)$, and 69 females $(43.6 \%)$. The overall sex ratio (1:0.78) was not significantly different from the expected 1:1 proportion (Chi-square test $(\chi 2)$; $\mathrm{p}>0.05)$. The females carapace width $(\mathrm{CW})$ ranged from 12.24 to $34.52 \mathrm{~mm}(24.26 \pm 0.79)$ (Table 1), and for males from 10.26 to 36.50 $\mathrm{mm}(23.07 \pm 0.80)$. A comparison of mean $\mathrm{CW}$ in both sexes showed no significant differences ( $t$-test; $p>0.05$ ), and the same resulted between immature and mature females (MannWhitney U test; $\mathrm{p}>0.05$ ).

The relative bimonthly frequencies of the four maturation stages found were obtained 
TABLE 1

Sodhiana iranica carapace width (CW) comparison of males and females from Eelood Area, Hormozgan Province, Southern Iran

\begin{tabular}{lllcccc}
\multicolumn{1}{c}{ Sex } & N & Mean $(\mathrm{mm})$ & S. E. & Max & Min \\
CW (mm) & Male & 89 & 23.07 & 0.80 & 36.50 & 10.26 \\
& Female (Total) & 69 & 24.26 & 0.79 & 34.52 & 12.24 \\
& Female (immature) & 20 & 18.87 & 0.49 & 28.32 & 12.24 \\
& Female (mature) & 49 & 30.87 & 0.42 & 34.52 & 29.43 \\
\hline
\end{tabular}

$(\mathrm{N}=$ sample number; S.E. $=$ standard error; Max= Maximum; Min= Minimum $)$.

for $S$. iranica females (Fig. 2). Spent females were mainly present from April to August (2012), with some spent females observed in April (2013). During the same months, stage II specimens were also present, with a slightly lesser extent. Stage III started in August (2012) and progressed rapidly, reaching a peak in October (2012). Maturation and spawning occurred from December (2012) to April (2013), when the frequency of stage IV specimens had the highest values. This stage peaked in February (2013), and showed signs of decline later in April (2013). Gametogenesis appeared to be continuous throughout the spawning period, as evident from the basal frequencies of stage III specimens during this period. The reproduction of S. iranica from the Eelood freshwater spring followed a single seasonal cycle, with the peak stage III in October (2012) and spawning occurring between December (2012) and April (2013). A low percentage, of females carrying either eggs or young ones, was observed from all samples.

The bimonthly fluctuation of oocytes diameter is given in figure 3 . The mean of oocyte diameters varied significantly between different months (ANOVA; $F=3.86 ; p<0.05$ ). The most significant increase in the oocyte mean diameter occurred between August (2012) and February (2013) (from $189.54 \pm 16.71$ to $466.05 \pm 67.80 \mu \mathrm{m}$, respectively) (ANOVA; $\mathrm{F}=3.52 ; \mathrm{p}<0.05)$. This pattern coincided with ovarian maturation stages and subsequent spawning during this period.

Kruskal-Wallis tests showed no significant differences in GSI values between different months (Kruskal-Wallis test; $\mathrm{df}=6 ; \mathrm{p}>0.05$ ). The Gonado-somatic indexes (GSI) reached

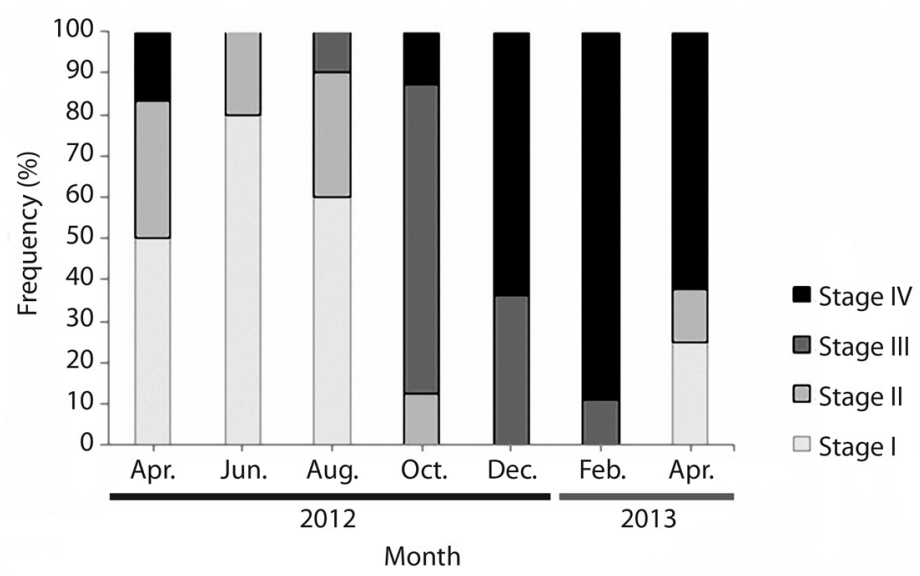

Fig. 2. Sodhiana iranica Sharifian, Kamrani, \& Sharifian, 2014. Frequency of maturation stages in adult females from Eelood Area, Hormozgan Province, Southern Iran. April 2012-April-2013. 


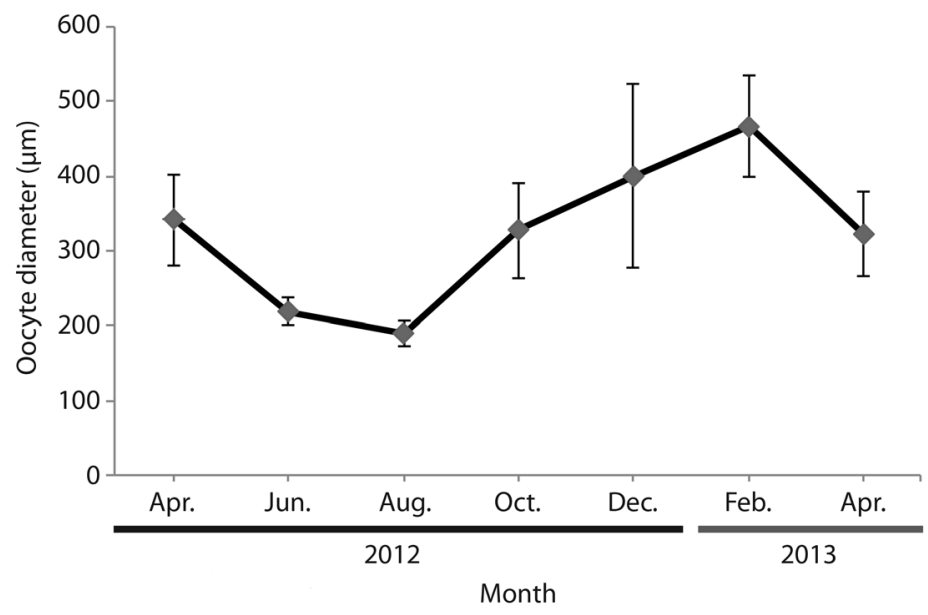

Fig. 3. Sodhiana iranica Sharifian, Kamrani, \& Sharifian, 2014. The bimonthly fluctuation of oocytes diameter at Eelood Area, Hormozgan Province, Southern Iran. Error bars \pm standard error (SE).

an annual peak in February (2013), and a drop was found in the index value for April (2013), indicating a single annual spawning event (Fig. 4). The Gonado-somatic indexes (GSI) values reached their annual minimum from June through October, after which the buildup of GSI was observed. The GSI values in April (2013) were similar to those of April (2012).

A significant difference in Hepato-somatic indexes (HSI) was observed between different months (Kruskal-Wallis test; $\mathrm{df}=6 ; \mathrm{p}<$
0.05). The HSI (\%) was observed lowest in June (2012), whereas a peak of hepatopancreas development was observed in April (2012) and February (2013), respectively (Fig. 5). The regression analysis showed that there is a weak correlation between GSI and HSI (\%) (F $=0.41 ; \mathrm{p}>0.05$, and $\left.\mathrm{R}^{2}=0.307\right)$. Macroscopic observation of the hepatopancreas resulted in the classification of four colors during the ovarian cycle. These colors were dark brown, dark cream, bright yellow, and dark yellow color.

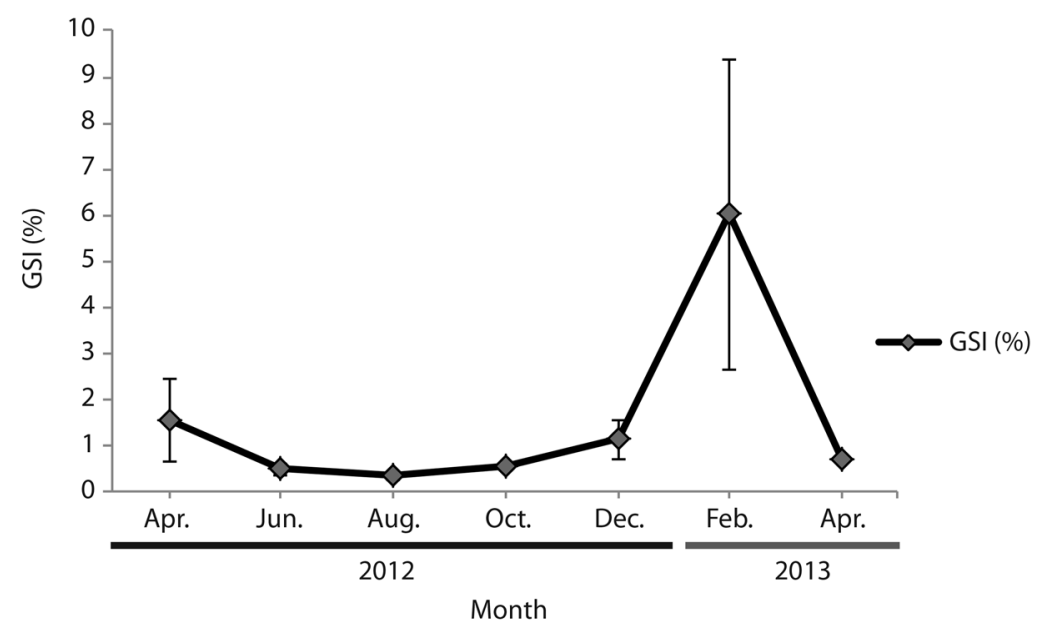

Fig. 4. Sodhiana iranica Sharifian, Kamrani, \& Sharifian, 2014. Temporal trends of the gonadosomatic index at Eelood Area, Hormozgan Province, Southern Iran. Error bars \pm standard error (SE). April 2012-April-2013. 


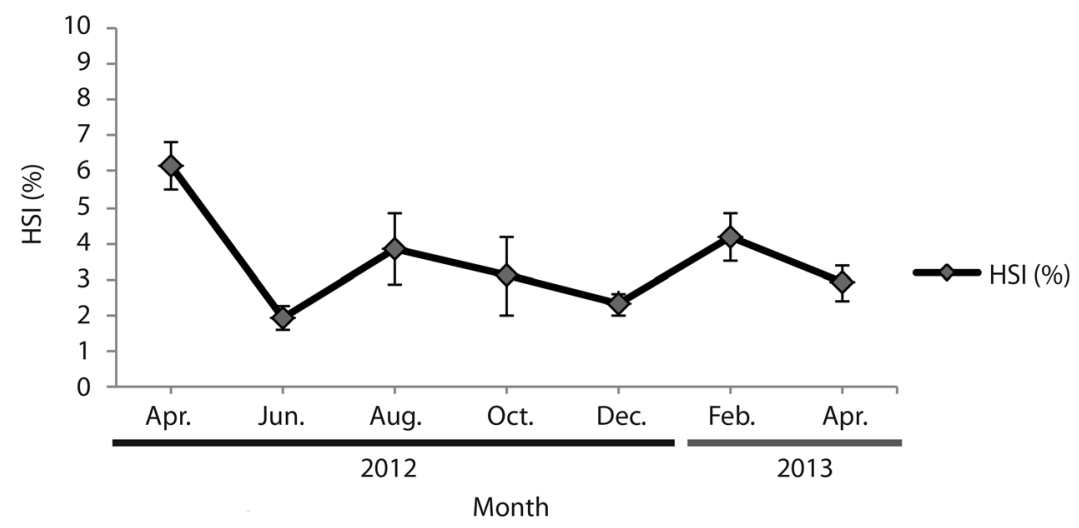

Fig. 5. Sodhiana iranica Sharifian, Kamrani, \& Sharifian, 2014. Temporal trends of the hepatosomatic index at Eelood Area, Hormozgan Province, Southern Iran. Error bars \pm standard error (SE). April 2012-April-2013.

\section{DISCUSSION}

This is a species found in local streams but is an important resource for local people. In terms of carapace width, any significant differences were observed between the sexes of $S$. iranica. Sex dimorphism in size is especially marked in aquatic brachyurans than in semiterrestrial and terrestrial ones (Pinheiro \& Fransozo, 1999). In this study, the overall sex ratio for $S$. iranica was not significantly different from the expected ratio $(1: 1)$. The sex ratio was found the same as in the freshwater crab Sinopotamon yangtsekiense (Tao, Wei, \& Nan-shan, 1994) and the crab Uca arcuata (Yamaguchi \& Henmi, 2008).

Regarding to GSI, hepato-somatic index (HSI), and the mean of oocyte diameter in $S$. iranica which showed a rising trend during spawning period December (2012) to April (2013), with a drop in April (2013); this behavior suggested that the crab $S$. iranica is a single seasonal breeder. Seasonal breeding pattern has been also reported for Travancoriana schirnerae (Devi \& Smija, 2013), Sodhiana rokitanskyi (Nakhodai, Kamrani, \& Mirzadeh, 2013), Sartoriana spinigera (Rahman, Rhaman, Ahmed, Mollah, \& Hossain, 2008), Sinopotamon yangtsekiense (Tao, Wei, \& Nan-shan, 1994), and Potamon koolooense (Joshi \& Khana, 1982). Like $S$. iranica, some gecarcinucid crabs have a short breeding season (Devi and Smija 2013).
The reproduction in tropical areas occur year round because environmental favorable conditions (Mouton \& Felder, 1995), whereas the breeding is expected to be restricted to certain months in subtropical areas (Pillay \& Nair, 1973). Nonetheless, exceptions to this hypothesis have been reported (Litulo, 2004).

Food availability is an important factor which triggers maturation and spawning (Wenner, 1977; Litulo, 2004). Regarding the breeding of $S$. iranica which was restricted to rainy and cold months, this suggests that ovarian maturation of $S$. iranica could be triggered by nutrient accumulation. Moreover, other contributing factors may be associated with the breeding activity such as temperature, salinity, oxygen, and photoperiod (Costa, \& Negreiros-Fransozo, 2003; Mantelatto, Faria, \& Garcia, 2003). Generally, female crabs prefer warmer water where they produce eggs more rapidly. Egg development time was considerably shortened by warm water (Fusaro, 1980). Food availability also has a direct effect on egg production (Wenner, 1977). Litulo (2005) suggests seasonal breeding patterns of crabs in subtropical areas may be based on the population's evolutionary histories or abiotic and biotic factors.

Like $S$. iranica, observations for low percentage of ovigerous females were seen by Devi and Smija (2013) for the freshwater crab 
Travancoriana schirnerae from India, and by Mansur and Hebling (2002) in the neotropical freshwater crab Sylviocarcinus australis from Brazil. The reason for low percentage of ovigerous females may be attributed to the behavior of these female crabs, as they remain in their burrows during the entire incubation period, and foraging decreases when compared to other activities of this particular life phase (Mansur \& Hebling, 2002).

There is a relationship between the hepatopancreas and ovary physiology in crustaceans. The carbon and lipid concentrations of hepatopancreas decrease during the ovarian maturation and subsequently, the concentrations of carbon and lipid in ovaries increase during this period (Felder \& Hasek, 2005). Regarding macroscopic observations, the $S$. iranica ovary increased in size and color during the ovarian maturation. The gradual increase in the size of the ovarian cells has been attributed to the deposit of lipid in the ovaries during vitellogenesis (Revathi, Iyapparaj, Munuswamy, \& Krishnan, 2012; Castiglioni, \& NegreirosFransozo, 2006; Gregati, Fransozo, López-Greco, \& Negreiros-Fransozo, 2010). The color changes observed in the hepatopancreas can be attributed to changes in its contents as previously reported (water, carbon, nitrogen, among others) (Felder, \& Hasek, 2005).

The information of reproductive biology of aquatic living resources, including GSI, ovarian development and reproductive season, is of priority for their optimum management and conservation. In this study we found that $S$. iranica is a single seasonal breeder. The information gathered from this study may be used as a baseline data for more comprehensive research in the future. An understanding of breeding period may also help protect females with eggs during the spawning season as part of the population and policy making.

\section{ACKNOWLEDGMENTS}

We are grateful to Hanieh Saeedi (Federal University of Espirito Santo) for her kind assistance in editing this paper. The authors also would like to acknowledge Aref Ghafori, Mansour Nami and Nima Nami for their field assistance in the Eelood region, Bastak, Iran.

\section{RESUMEN}

Biología reproductiva del cangrejo de agua dulce Sodhiana iranica (Brachyura: Gecarcinidae) del sur de Irán. El cangrejo agua dulce Sodhiana iranica es un cangrejo gecarcinucido que ha sido recientemente encontrado en el sur de Irán. Este trabajo examina algunos aspectos de la reproducción del cangrejo de agua dulce $S$. Iranica en el manantial Eelood del sur de Irán. Los cangrejos se muestrearon al azar entre abril 2012 y abril 2013 cada dos meses. Las mediciones del índice gonadosomático, el hepatosomático (HSI), el diámetro de los ovocitos y las observaciones de las etapas de maduración de los especímenes capturados, revelaron un único ciclo reproductivo estacional. La maduración y el desove se produjeron entre Diciembre 2012 y Abril 2013. El pico del índice hepatosomático se observó en Abril 2012 y Febrero 2013, respectivamente, y resultó más significativo el incremento en la media del diámetro de los ovocitos, que se produjo entre Agosto 2012 y Febrero 2013. En este estudio, se encontró que $S$. iranica se reproduce una vez al año estacionalmente. Por lo anterior, la gestión correcta durante el ciclo reproductivo de esta especie es necesaria para mantener la naturaleza y salud del stock de cangrejo.

Palabras clave: reproducción, índice gonadosomático (GSI), de agua dulce, cangrejos, decápodos.

\section{REFERENCES}

Biswas, S. P. (1993). Manual of methods in fish biology. New Delhi, India: South Asian publisher.

Castiglioni, D. S., \& Negreiros-Fransozo, M. L. (2006). Physiologic sexual maturity of the fiddler crab Uca rapax (Smith, 1870) (Crustacea, Ocypodidae) from two mangroves in Ubatuba, Brazil. Brazilian Archives of Biology and Technology, 49, 239-248.

Clarke, A. (1977). Seasonal variations in total lipid content of Chorismus antarcticus (Pfeffer)-(Crustacea-Decapoda) at South Georgia. Journal of Experimental Marine Biology and Ecology, 27, 93-106.

Costa, T. M., \& Negreiros-Fransozo, M. L. (2003). Population biology of Uca thayeri Rathbun, 1900 (Brachyura, Ocypodidae) in a subtropical South American mangrove area: results from transect and catch-perunit-effort techniques. Crustaceana, 75, 1201-1218.

Cumberlidge, N., Ng, P. K. L.,Yeo, D. C. J., Magalhães, C., Campos, M. R., Alvarez, F., Naruse, T., Daniels, S. R., Esser, L. J., Attipoe, F. Y. K., Clotilde-Ba, F. L., Darwall, W., McIvor, A. E. M., Baillie, J., 
Collen, B., \& Ramj, M. (2009). Freshwater crabs and the biodiversity crisis: Importance, threats, status, andconservation challenges. Biological Conservation, 142, 1665-1673.

Devi, A. R. S., \& Smija, M. K. (2013). Reproductive biology of the freshwater crab, Travancoriana schirnerae Bott, 1969 (Brachyura: Gecarcinucidae). Indian Journal of Fisheries, 60, 13-21.

Felder, D. L., \& Hasek, B. E. (2005). Biochemical composition of ovary, embryo, and hepatopancreas in the grapsoid crabs Armases cinereum and Sesarma $n r$ reticulatum (Crustacea, Decapoda). Comparative Biochemistry and Physiology, 140, 455-463.

Fusaro, C. (1980). Temperature and egg production by sand crab Emertia analoga (Decapoda Hippidae). Crustaceana, 38, 55-60.

Giese, A. C. (1966). Lipids in the economy of marine invertebrates. Physiological Reviews, 46, 244-290.

Gregati, R. A., Fransozo, V., Lopez-Greco, L. S., \& Negreiros-Fransozo, M. L. (2010). Reproductive cycle and ovarian development of the marine ornamental shrimp Stenopus hispidus in captivity. Aquaculture, 306, 185-190.

Hartnoll, R. G., Broderick, A. C., Godley, B. G., \& Saunders, K. E. (2009). Population structure of the land crab Johngarthia lagostoma on Ascension Island. Journal of Crustacean Biology, 29(1), 57-61.

Hartnoll, R. G., Broderick, A. C., Godley, B. G., Musick, S., Pearson, M., Stroud, S. A., \& Saunders, K. E. (2010). Reproduction in the land crab Johngarthia lagostoma on Ascension Island. Journal of Crustacean Biology, 30(1), 83-92.

Henmi, Y., \& Koga, H. (2009). Growth and reproduction of the intertidal dotillid crab Ilyoplax deschampsi. Journal of Crustacean Biology, 29, 516-522.

Joshi, P. C., \& Khanna, S. S. (1982). Seasonal changes in the ovary of a freshwater crab, Potamon koolooense (Rathbun). Animal Sciences, 5, 451-462.

Kamrani, E., Ng, P. K. L., Mirzadeh, M., \& Nakhodai, S. (2009). The marsh crab, Sodhiana rokitanskyi (Pretzmann, 1971) (Decapoda, Brachyura, Gecarcinucidae) from southern Iran. Zootaxa, 2305, 24-32.

Keikhosravi, A., \& Schubart, C. D. (2014). Description of a new freshwater crab species of the genus Potamon (Decapoda, Brachyura, Potamidae) from Iran, based on morphological and genetic characters. In D. C. J. Yeo, N. Cumberlidge, \& S. Klaus (Eds.), Advances in freshwater decapod systematics and biology (pp. 115133). Heidelberg, Germany: Brill publisher.

Kumar, S. M., Xiao, Y., Venema, S., \& Hooper, G. (2003). Reproductive cycle of the blue swimmer crab, Portunus pelagicus, of southern Australia. Journal of the
Marine Biological Association of the United Kingdom, 83, 983-994.

Lestang, S. D., Hall, N. G., \& Potter, L. C. (2003). Reproductive biology of the blue swimmer crab (Portunus pelagicus, Decapoda: Portunidae) in five bodies of water on the west coast of Australia. Fishery Bulletin, 101, 745-757.

Litulo, C. (2004). Reproductive aspects of a tropical population of the fiddler crab Uca annulipes $(\mathrm{H}$. Milne Edwards, 1837) (Brachyura: Ocypodidae) at Costa do Sol Mangrove, Maputo Bay, southern Mozambique. Hydrobiologia, 525, 157-173.

Litulo, C. (2005). Population structure and reproductive biology of the fiddler crab Uca inversa (Hoffman, 1874) (Brachyura: Ocypodidae). Acta Oecologica, 27, 135-141.

Liu, H. C., \& Jeng, M. S. (2005). Reproduction of Epigrapsus notatus (Brachyura: Gecarcinidae) in Taiwan. Journal of Crustacean Biology, 25, 135-140.

Lopez Greco, L. S., Hernández, J. E., Bolaños, J. E., Rodríguez, E. M., \& Hernández, G. (2000). Population features of Microphrys bicornutus Latreille, 1825 (Brachyura, Majidae) from Isla Margarita, Venezuela. Hydrobiologia, 439, 151-159.

Mantelatto, F. L. M., Faria, F. C. R., \& Garcia, R. B. (2003). Biological aspects of Mithraculus forceps (Brachyura: Mithracidae) from Anchieta Island, Ubatuba, Brazil. Journal of the Marine Biological Association of the United Kingdom, 83, 789-791.

Mansur, C. B., \& Hebling, N. S. (2002). Análise comparativa entre a fecundidade de Dilocarcinus pagei Stimpsone Sylviocarcinus australis Magalhães \& Türkay (Crustacea, Decapoda, Trichodactylidae) no Pantanal do Rio Paraguai, Porto Murtinho, Mato Groso do Sul. Revista Brasileira de Zoologia, 19, 797-805.

Mouton, E. C., \& Felder, D. L. (1995). Reproduction of the fiddler crabs Uca longisignalis and Uca spinicarpa in a Gulf of Mexico salt marsh. Estuaries, 18, 469-481.

Nakhodai, S., Kamrani, E., \& Mirzadeh, M. (2013). Studies on the Morphological Aspects of the Reproductive Marsh Crab, Sartoriana rokitanskyi, in Geno (Southern Iran). Switzerland Research Park Journal, 102, 293-299.

Nasrollahzadeh, A., Noveirian, H. A., \& Soutohian, F. (2011). First report on freshwater crab species (Potamon bilobatum) in the altitudes of Guilan (Lakan area). Caspian Journal of Environmental Sciences, 9, 279-283.

Ng, P. K. L. (1988). The Freshwater Crabs of Peninsular Malaysia and Singapore. National University of Singapore: Shinglee Press. 
Ng, P. K. L., Guinot, D., \& Davie, P. (2008). Systema brachyuorum: part I. An annotated checklist of extant brachyuran crabs of the World. Raffles Bulletin of Zoology, 17, 1-286.

Oh, C. W., Kim, J. Y., Jeong, I. J., Suh, H. L., \& Cho, Y. K. (2006). Reproduction and population dynamics of Leptochela gracilis (Decapoda: Pasiphaeidae) on the western coast of Korea, Yellow Sea. Journal of the Marine Biological Association of the United Kingdom, 86, 113-120

Omolara, A. L. A. (2010). Reproductive biology of the blue crab, Callinectes amnicola (De Rocheburne) in the Lagos Lagoon, Nigeria. Turkish Journal of Fisheries and Aquatic Sciences, 10, 1-7.

Pathre, R. F., \& Mina, P. (2010). Breeding cycle and Fecundity Freshwater crab Barytelphosa cunicularis (Decapoda, Potamonidae). World Journals of Zoology, 5, 96-102.

Pretzmann, G. (1971). Ergebnisse einiger Sammelreisen nach Vorderasien I. Teil: Zwei neue Unterarten von Süßwasserkrabben. Annalen des Naturhistorischen Museums in Wien, 75, 473-475.

Pillay, K. K., \& Nair, N. B. (1973). Observation on the breeding biology of some crabs from the south-west coast of India. Journal of the Marine Biological Association of the United Kingdom, 15, 754-770.

Pinheiro, M. A. A., \& Fransozo, A. (1999). Reproductive behavior of the swimming crab Arenaeus cribrarius (Lamarck, 1818) (Crustacea, Brachyura, Portunidae) in captivity. Bulletin of Marine Sciencie, 64, 243-253.

Revathi, P., Iyapparaj, P., Munuswamy, N., \& Krishnan, M. (2012). Vitellogenesis during the ovarian development in freshwater female prawn Macrobrachium rosenbergii (De Man). International Journal of Aquatic Science, 3, 13-27.

Rhaman, M. A., Rhaman, M. M., Ahmed, A. T. A., Mollah, A. R., \& Hossain, M. A. (2008). A survey on the diversity of freshwater srabs in some wetland ecosystems of Bangladesh. International Journal of Sustainable Crop Production (IJSCP), 3, 10-17.

Sahoo, D., Panda, S., \& Guru, B. C. (2011). Studies on reproductive biology and ecology of blue swimming crab Portunus pelagicus from Chilika Lagoon, Orissa, India. Journal of the Marine Biological Association of the United Kingdom, 91, 257-264.

Sallam, W. S. (2005). Population structure and biology of the crab Dotilla sulcata from Elgharqana Mangrove, South Sinai, Red Sea. Egyptian Journal of Aquatic Research, 31, 314-325.

Sastry, A. N. (1983). Ecological aspects of reproduction. In F. J. Vernberg, \& W. Vernberg (Eds.), The Biology of Crustacea. New York: Academic Press.

Sharifian, S., Kamrani, E., \& Sharifian, S. (2014). A new species of freshwater crab of the genus Sodhiana Yeo \& Ng 2012 (Decapoda: Brachyura: Gecarcinucidae) from southern Iran. Zootaxa, 3878(5), 485-490.

Sharifian, S., Kamrani, E., Safaie, M., \& Sharifian, S. (2015). Oogenesis and ovarian development in the freshwater crab Sodhiana iranica from south of Iran. Tissue and Cell, 47, 213-220.

Sharifian, S., \& Kamrani, E. (2015). The morphometric variations of freshwater crab Sodhiana iranica from Southern Iran. Journal of the Persian Gulf (Marine Science), 6, 43-52.

Tao, C., Wei, L., \& Nan-shan, D. (1994). Growth, reproduction and population structure of the freshwater crab Sinopotamon yangtsekiense bott, 1967, from Zhejianc, China. Chinese Journal of Oceanology and Limnology, 12, 84-90.

Wenner, A. W. (1977). Food supply feeding habits and egg production in pacific mole crabs Hippa pacifica. Pacific Science, 31, 39-48.

Yamaguchi, T., \& Henmi, A. (2008). Cheliped differentiation and sex ratio of the fiddler crab Uca arcuata. Crustacean Research, 37, 74-79.

Yeo, C, J. D., Ng, P. K. L., Cumberlidge, N., Magalhães, C., Daniels, S. R., \& Campos, M. R. (2008). Global diversity of crabs (Crustacea: Decapoda: Brachyura) in freshwater. Hydrobiologia, 595, 275-286.

Zar, J. H. (1996). Biostatistical analysis (3rd edition). Upper Saddle River, New Jersey: Prentice-Hall. 
